\title{
DEBIUTY
}

Katarzyna Schatt-Babińska

katarzyna.schatt@gmail.com

orcid.org/0000-0002-8289-3265

Uniwersytet Łódzki

Wydział Filozoficzno-Historyczny

ul. Aleksandra Kamińskiego 27a

90-219 Łódź

\section{Finansowanie prac remontowych przy zabytkach prywatnych - akredytywa i gwarancja bankowa w służbie zabytkom}

Zarys problematyki

Financing renovation works on private monuments letters of credit and bank guarantees in the service of monuments Outline of issues

Summary: According to the law, the owner of a monument must take care of it properly. His duties include carrying out necessary repairs to the monument, including covering their costs (Articles 5 and 28 of the Act of $23^{\text {rd July }} 2003$ on the Protection of Monuments and the Guardianship of Monuments). This article will analyze the possibility of securing necessary funds for renovation in the event that a monument is sold by the local government to a private investor. Typically, the guarantor of a bilateral agreement is an independent third party. In commercial transactions, a bank is often used as a guarantor (as an independent institution). There are two particularly noteworthy options used by banks in this context: letters of credit and bank guarantees. These are solutions which have been tested and relied upon in trade. So why not make use of proven methods from trade and apply them to the protection of monuments? Although this would require the introduction of specific solutions via 


\section{DEBIUTY}

Katarzyna Schatt-Babińska

legal provisions, it is worth considering such changes, as they could protect monuments from destruction.

Keywords: letter of credit, bank guarantee, financing the renovation of monuments

Streszczenie: Zgodnie z przepisami, właściciel zabytku ma obowiązek opieki i ochrony zabytku, w tym również do przeprowadzenia niezbędnych przy zabytku prac w celu jego zachowania (art. 5 i 28 ustawy z dnia 23 lipca 2003 r. o ochronie zabytków i opiece nad zabytkami). Ponoszenie kosztów związanych z zachowaniem zabytku jest jednym z obowiązków właściciela. W artykule zostały przeanalizowane możliwości zabezpieczenia niezbędnych funduszy na remont w przypadku sprzedaży prywatnemu inwestorowi zabytku przez Skarb Państwa lub jednostkę samorządu terytorialnego. Dwie instytucje z zakresu prawa bankowego są szczególnie godne uwagi: akredytywa i gwarancja bankowa. Celem opracowania jest zbadanie wykorzystania potencjału tych instytucji w ochronie zabytków.

Słowa kluczowe: akredytywa, gwarancja bankowa, finansowanie prac przy zabytku

\section{Wstęp}

Lustracje terenowe podjęte przez oddziały Narodowego Instytutu Dziedzictwa w latach 2009-2016 na reprezentatywnej grupie zabytków nieruchomych wpisanych do rejestru wykazały, że:

ponad 2/3 zabytków nieruchomych figurujących w rejestrze zabytków wymaga różnego rodzaju prac remontowych, w mniejszym zakresie w przypadku obiektów posiadających słabe objawy zniszczenia, a w przypadku umiarkowanie silnych i silnych objawów zniszczenia - prac kompleksowych i pilnych. Zaprezentowane poniżej wartości procentowe warto również wyrazić w postaci wartości bezwzględnych. Owe 6,5\% najsilniej zniszczonych obiektów to w całości operatu niemal 4400 obiektów ${ }^{1}$.

W grupie zabytków nieruchomych o bardzo dobrym ogólnym stanie zachowania zabytki należące do osób prywatnych stanowiły najniższy odsetek².

Finansowanie prac przy zabytku jest obowiązkiem właściciela. W niniejszym artykule przeanalizowane zostaną możliwości zabezpieczenia niezbędnych fundu-

1 M. Rozbicka (red.), Raport o stanie zachowania zabytków nieruchomych w Polsce. Zabytki wpisane do rejestru zabytków (księgi rejestru A i C), Narodowy Instytut Dziedzictwa, Warszawa 2017, s. 99.

2 Ibidem, s. 100. 
szy na remont w przypadku sprzedaży zabytku przez Skarb Państwa lub jednostkę samorządu terytorialnego (dalej: JST). Tylko w tym przypadku istnieje możliwość wpłynięcia na to, kto kupi zabytek (art. 13 ust. 4 ustawy z dnia 21 sierpnia 1997 r. o gospodarce nieruchomościami ${ }^{3}$, dalej: u.g.n.). Transakcje kupna-sprzedaży pomiędzy osobami fizycznymi czy prawnymi nie podlegają nadzorowi ani wojewódzkiego konserwatora zabytków (dalej: WKZ), ani JST. Zgodnie z art. 28 ust. 1 pkt 4 ustawy z dnia 23 lipca 2003 r. o ochronie zabytków i opiece nad zabytkami ${ }^{4}$, dalej: u.o.z.), właściciel ma obowiązek jedynie powiadomienia WKZ o zmianach dotyczących stanu prawnego zabytku. Na uwadze trzeba również mieć fakt, że obrót nieruchomościami Skarbu Państwa czy nieruchomościami samorządowymi, zgodnie $z$ art. 37 u.g.n., odbywa się w drodze publicznego przetargu ${ }^{5}$. Organizowany przetarg może przybrać jedną z czterech form, jakie umożliwia art. 40 ust. 1 u.g.n.: przetarg ustny nieograniczony, przetarg ustny ograniczony, przetarg pisemny nieograniczony, przetarg pisemny ograniczony. Dodatkowo, zgodnie z art. 26 u.o.z.:

W umowie sprzedaży, zamiany, darowizny lub dzierżawy zabytku nieruchomego wpisanego do rejestru, stanowiącego własność Skarbu Państwa lub jednostki samorządu terytorialnego, przy określaniu sposobu korzystania z tego zabytku należy nałożyć, jeżeli stan zachowania zabytku tego wymaga, na nabywcę lub dzierżawcę obowiązek przeprowadzenia w określonym terminie niezbędnych prac konserwatorskich przy tym zabytku.

\section{Obowiązki właściciela w zakresie przeprowadzenia prac przy zabytku}

Zgodnie z przepisami ustawy o ochronie zabytków i opiece nad zabytkami, właściciel zabytku zobligowany jest do odpowiedniego zajmowania się nimº,

3 Ustawa z dnia 21 sierpnia 1997 r. o gospodarce nieruchomościami, tekst jedn. Dz.U. z 2020 r., poz. 65 ze zm.

4 Ustawa z dnia 23 lipca 2003 r. o ochronie zabytków i opiece nad zabytkami, tekst jedn. Dz.U. z 2020 r., poz. 282 ze zm.

5 Wyjątki od zasady publicznego przetargu - zbycie nieruchomości na rzecz osoby, której przysługuje pierwszeństwo w nabyciu na podstawie art. 34 u.g.n., zbycie na rzecz Skarbu Państwa lub sprzedaż między JST, zbycie następuje w drodze zamiany lub darowizny, zbycie nieruchomości następuje na rzecz jej użytkownika wieczystego, sprzedaży w celu polepszenia warunków zagospodarowania nieruchomości przyległej, w przypadku gdy nieruchomość ma stanowić wkład niepieniężny do spółki albo wyposażenie nowo tworzonej państwowej lub samorządowej osoby prawnej, lub majątek tworzonej fundacji, sprzedawana jest na rzecz osoby zarządzającej specjalną strefą ekonomiczną (w przypadku, gdy nieruchomość znajduje się na jej terenie), przedmiotem zbycia jest udział w nieruchomości, a zbycie następuje na rzecz innych współwłaścicieli nieruchomości, sprzedaż następuje na rzecz kościołów, związków wyznaniowych czy Krajowego Zasobu Nieruchomości, jest zbywana w ramach partnerstwa publiczno-prywatnego, jest zbywana na rzecz inwestora realizującego inwestycję: $w$ zakresie budowy obiektu energetyki jądrowej, w zakresie terminalu, w zakresie sieci przesyłowej, zakresie infrastruktury dostępowej (art. 37 ust. 2 pkt 1-18 u.g.n.).

6 Zgodnie z art. 5 u.o.z., opieka nad zabytkiem polega w szczególności na zapewnieniu warunków do naukowego badania i dokumentowania zabytku; prowadzeniu prac konserwatorskich, restauratorskich i robót budowlanych przy zabytku, zabezpieczeniu i utrzymaniu zabytku oraz jego otoczenia w jak najlepszym 


\section{DEBIUTY}

Katarzyna Schatt-Babińska

w tym również do przeprowadzenia niezbędnych przy zabytku prac w celu jego zachowania.

Według art. 110 u.o.z., niedostateczna opieka nad zabytkiem podlega karze aresztu, ograniczenia wolności lub grzywny. W przypadku niezabezpieczenia zabytku przed uszkodzeniem, zniszczeniem, zaginięciem lub kradzieżą, zgodnie z art. 110 ust. 2, można orzec nawiązkę do wysokości dwudziestokrotnego minimalnego wynagrodzenia na wskazany cel społeczny związany z opieką nad zabytkami. W 2018 r. w przepisach ustawy o ochronie zabytków i opiece nad zabytkami wprowadzono kary administracyjne. Za naruszenie obowiązków informacyjnych właściciel podlega karze pieniężnej w wysokości od 500 do 2000 zł (art. 107a u.o.z.), za podejmowanie działań bez pozwolenia lub wbrew pozwoleniu WKZ właściciel podlega karze pieniężnej w wysokości od 500 do 500 tys. zł (art. 107d u.o.z.), taka sama wysokość kary jest za niewykonanie zaleceń pokontrolnych WKZ (art. 107e u.o.z.). Środki pieniężne uzyskane z tytułu kar administracyjnych przekazywane są do Narodowego Funduszu Ochrony Zabytków (dalej: Fundusz), który - zgodnie z art. 83b u.o.z. jest państwowym funduszem celowym? ${ }^{7}$. Środki na nim gromadzone będą wykorzystywane na dofinansowanie niezbędnych prac przy zabytkach wpisanych na Listę Skarbów Dziedzictwa oraz do rejestru zabytków. Konto Funduszu zasilane jest środkami z administracyjnych kar pieniężnych, orzekanych od 1 stycznia 2018 r. na podstawie art. 107a-107d u.o.z. oraz z zasądzonych przez sąd nawiązek w sprawach przestępstw zniszczenia lub uszkodzenia zabytku (art. 108 u.o.z.).

Przewidziane w przepisach kary nie dają jednak pewności przywołania właściciela do porządku i przeprowadzenia niezbędnych prac przy zabytku w celu jego zachowania. Należy mieć również na uwadze, że - po pierwsze - potrzeby finanso-

stanie, korzystaniu z zabytku w sposób zapewniający trwałe zachowanie jego wartości; popularyzowaniu i upowszechnianiu wiedzy o zabytku. W przypadku zagospodarowania zabytku na cele użytkowe, zgodnie z art. 25 u.o.z. opieka nad zabytkiem polega na prowadzeniu dokumentacji konserwatorskiej określającej stan zachowania zabytku i możliwości jego adaptacji, na uzgadnianiu z WKZ programu prac, jak i zagospodarowania zabytku wraz z jego otoczeniem. Zgodnie $z$ art. 28 u.o.z., opieka nad zabytkiem polega na zawiadamianiu WKZ o każdym uszkodzeniu, zniszczeniu zabytku niezwłocznie po wystąpieniu takiego zdarzenia; o każdym zagrożeniu dla zabytku i zmianach dotyczących stanu prawnego zabytku, nie później niż w terminie miesiąca od dnia ich wystąpienia lub powzięcia o nich wiadomości. Zgodnie z art. 29 u.o.z., opieka nad zabytkiem polega na udostępnianiu obiektu organom ochrony w celu przeprowadzenia badań. Zgodnie z art. 36 u.o.z., odpowiednie zajmowanie się zabytkiem wiąże się z uzyskaniem od WKZ zgody takie działania przy zabytku jak: prowadzenie prac konserwatorskich, restauratorskich i budowlanych; wykonywanie robót budowlanych w otoczeniu zabytku; prowadzenie badań konserwatorskich, architektonicznych oraz archeologicznych; przemieszczanie zabytku nieruchomego; dokonywanie podziału zabytku; dokonanie zmiany przeznaczenia zabytku lub sposobu korzystania; umieszczanie na zabytku urządzeń technicznych, tablic, reklam i napisów; podejmowanie innych działań, które mogłyby naruszyć substancję zabytkową obiektu. Zgodnie z art. 49 u.o.z., opieka nad zabytkiem polega na realizacji nakazu WKZ wykonania prac konserwatorskich lub robót budowlanych przy zabytku (jeżeli ich wykonanie według WKZ jest niezbędne dla zachowania obiektu).

7 Narodowy Fundusz Ochrony Zabytków został powołany na podstawie art. 1 pkt 11 ustawy z dnia 22 czerwca 2017 r. o zmianie ustawy o ochronie zabytków i opiece nad zabytkami oraz niektórych innych ustaw (Dz. U. poz. 1595). 
wania zastępczego wykonania prac są olbrzymie ${ }^{8}$, po drugie - procedura administracyjna nakładania kar, która umożliwia drogę odwoławczą, z dużym prawdopodobieństwem wydłuży czas spływania środków do Funduszu, po trzecie - nie ma pewności co do skuteczności ściągania wyżej wymienionych kar. Zgodnie z informacjami podanymi przez Katarzynę Zalasińską:

Na 31 grudnia 2018 r. należności względem Funduszu wynosiły 1365900 zł, a rzeczywiste wpłaty 649271,12 zł. Natomiast tytułem nawiązek na konto Funduszu wpłynęło 50 173,91 zł ze 102 446,57 zł orzeczonych na podstawie 20 wyroków karnych 9

Ustawa o ochronie zabytków daje możliwość wykonania zastępczego prac przy zabytku wpisanym do rejestru na mocy decyzji wydanej przez WKZ. W decyzji tej określane są: wysokość wierzytelności Skarbu Państwa z tytułu wykonania zastępczego prac, termin ich realizacji oraz ich zakres (art. 49 ust. 3 u.o.z.). Wierzytelność Skarbu Państwa podlega zabezpieczeniu przymusową hipoteką na tej nieruchomości (art. 49 ust.4 u.o.z.). Jednak częstym wytłumaczeniem inwestora braku remontu jest brak funduszy, więc nawet w przypadku wykonania zastępczego prac nie będzie możliwości wyegzekwowania zwrotu związanych z nimi kosztów.

W razie wystąpienia zagrożenia zniszczenia czy też uszkodzenia zabytku nieruchomego wpisanego do rejestru, na wniosek WKZ starosta może wydać decyzję o zabezpieczeniu nieruchomości w formie czasowego zajęcia - do czasu usunięcia zagrożenia (art. 50 ust. 3 u.o.z.). Ustawa przewiduje również możliwość wywłaszczenia zabytku wpisanego do rejestru z przeznaczeniem na cele kultury, oświaty lub turystyki - także na wniosek WKZ na rzecz Skarbu Państwa lub gminy. Może mieć to miejsce w przypadku braku możliwości usunięcia zagrożenia, jakim jest zniszczenie czy uszkodzenie obiektu (art. 50 ust. 4 pkt 2 u.o.z.). Wywłaszczenia dokonuje się na podstawie norm prawnych zawartych w ustawie o gospodarce nieruchomościami, co niesie ze sobą konieczność wypłacenia właścicielowi odszkodowania w wysokości wartości rynkowej zabytkowej nieruchomości (art. 50 ust. 4 pkt 1 u.o.z.). Jednak $w$ wielu przypadkach nawet wywłaszczenie nie jest pomocne w zachowaniu obiektu, ponieważ WKZ nie posiada dostatecznych środków na ratowanie zabytków. Rozwiązaniem problemu byłaby możliwość dokładnego sprawdzenia, czy inwestor kupujący zabytek posiada fundusze, by się nim opiekować. Jednak obecnie WKZ nie dysponuje instrumentem do zbadania stanu finansowego inwestora, który chce kupić zabytek od jednostki samorządu terytorialnego czy Skarbu Państwa. Nie może więc sprawdzić, czy dana osoba jest w stanie sfinansować niezbędne prace przy zakupionym obiekcie.

\footnotetext{
8 M. Rozbicka (red.), op. cit., s. 369.

9 K. Zalasińska, Narodowy Fundusz Ochrony Zabytków - w kierunku systemowych zmian w ochronie zabytków, „Cenne, Bezcenne, Utracone” 2019, nr 1-2, http://cennebezcenne.pl/wp-content/uploads/2019/09/20191-2-ZALASINSKA.pdf [dostęp: 1.06.2020].
} 


\section{DEBIUTY}

Katarzyna Schatt-Babińska

Zgodnie $z$ art. 26 ust. 1 u.o.z., w umowie sprzedaży, zamiany, darowizny lub dzierżawy zabytku nieruchomego wpisanego do rejestru, stanowiącego własność Skarbu Państwa lub JST, przy określaniu sposobu korzystania z tego zabytku należy nałożyć na nabywcę lub dzierżawcę obowiązek przeprowadzenia niezbędnych prac konserwatorskich przy tym zabytku, jeżeli wymaga tego stan jego zachowania. Stosownie do art. 29 ust. 2 u.g.n., jeżeli przedmiotem umowy o oddanie nieruchomości gruntowej w użytkowanie wieczyste jest zabytek wpisany do rejestru, to przy określaniu sposobu korzystania z tej nieruchomości w razie potrzeby można nałożyć na nabywcę obowiązek odbudowy lub remontu, określając odpowiedni termin (art. 29 ust. 2 u.g.n.). Przepis ten z pewnością nie eliminuje ryzyka sprzedaży zabytku nieuczciwemu inwestorowi.

Obecnie w przypadku sprzedaży zabytku przez gminę Łódź do przetargu zostają dopuszczone jedynie podmioty mające uzgodniony z WKZ wstępny plan zagospodarowania i użytkowania zabytku, które nie mają niespełnionych nakazów przeprowadzenia prac $w$ stosunku do innych obiektów ${ }^{10}$. W umowie sprzedaży stosuje się zapisy umożliwiające zwrot nieruchomości w razie nieprzeprowadzenia prac czy działania przez nabywcę na szkodę obiektu. W takim przypadku zabytek wraca do rąk gminy, jednak nie jest to dobre rozwiązanie, jeśli gmina nie posiada funduszy na przeprowadzenie niezbędnych prac dla jego ocalenia. Priorytetem nie jest powrót zabytku do gminy, tylko ochrona przed niszczeniem.

Należy się zastanowić, jak sprawić, by pieniądze na remont w przypadku sprzedaży nieruchomości przez JST czy Skarb Państwa były gwarantowane. W tej sytuacji jest kilka rozwiązań: można polegać na dobrej woli właściciela, szkolić urzędników lub wykorzystać trzeci podmiot budzący powszechne zaufanie. Zazwyczaj jako gwaranta dwustronnej umowy wykorzystuje się niezależną (niezwiązaną z żadną ze stron) stronę trzecią.

Głównym czynnikiem niewykonania przy zabytku niezbędnych dla jego zachowania prac jest brak pieniędzy zarówno ze strony konserwatora, który nie posiada funduszy na zastępcze wykonanie prac ${ }^{11}$, jak i ze strony inwestora, który stwierdza, że nagle zmieniła się jego sytuacja materialna. Nasuwa się pytanie: czy taka sytuacja była możliwa do przewidzenia i czy nie można się przed takimi sytuacjami zabezpieczyć?

Okazuje się, że obrońcy zabytków nie byli pierwszymi, którzy spotkali się z takim problemem. Przedsiębiorcy już znaleźli rozwiązanie, jak zabezpieczyć realiza-

10 Rozmowa z Wojciechem Szygendowskim - WKZ w Łodzi w latach 2005-2016, przeprowadzona w marcu 2019 r. w ramach mojej pracy doktorskiej pt. Zabytki nieruchome w rękach prywatnych - historia, zagadnienia ochrony i konserwacji na przykładach obiektów wpisanych do rejestru zabytków w Łodzi, przygotowanej pod kierunkiem prof. dr. hab. K. Stefańskiego, obronionej 16 stycznia 2020 r. na Wydziale Filozoficzno-Historycznym Uniwersytetu Łódzkiego.

11 „W latach 2010-2016 remonty zastępcze były prowadzone tylko w dwóch województwach, a kwoty przeznaczane na ten cel nie były zbyt wysokie. Pamiętać oczywiście należy, że WKZ (a co najmniej większość z nich) dysponują bardzo szczupłymi środkami finansowymi" (M. Rozbicka (red.), op. cit., s. 348-349). 
cję umowy przez kontrahenta, bo przecież - wyłączając instytucjonalność urzędów - dochodzi do zawarcia transakcji pomiędzy kontrahentami. Przedsiębiorcy z powodzeniem zabezpieczają swoje umowy za pomocą instrumentów finansowych gwarantowanych przez stronę trzecią - banki. W ofertach banków istnieją dwa produkty szczególnie godne uwagi: akredytywa i gwarancja bankowa.

\title{
Akredytywa dokumentowa
}

Akredytywa dokumentowa w rozumieniu przepisów Prawa bankowego to forma rozliczeń za pośrednictwem banku (art. 85 ustawy z dnia 29 sierpnia 1997 r. Prawo bankowe ${ }^{12}$ ). Zgodnie $z$ art. 5 ust. 1 pkt 4 Prawa bankowego, otwieranie i potwierdzanie akredytywy należą do czynności bankowych. Sama akredytywa wykorzystywana jest głównie przy transakcjach zwiększonego ryzyka. Przyglądając się działaniu akredytywy w transakcjach handlowych, można stwierdzić, że jej

\begin{abstract}
istotą jest własne i nieodwołalne zobowiązanie banku działającego na zlecenie podmiotu (zwykle jest to kupujący towar lub importer towaru) do zapłaty określonej kwoty pieniężnej na rzecz beneficjenta akredytywy (zwykle jest nim sprzedający towar lub jego eksporter) pod warunkami określonymi w akredytywie. Zapłata dokonywana jest na rzecz beneficjenta przez bank "otwierający” akredytywę i uzależniona jest od spełnienia przez beneficjenta warunków, z których najważniejszym jest warunek przedłożenia przez niego we wskazanym banku dokumentów określonych w akredytywie, którymi najczęściej są dokumenty handlowe. Zapłata na podstawie tych dokumentów nastąpi tylko wtedy, gdy w ocenie banku zostały one wystawione zgodnie ze wszystkimi warunkami i terminami określonymi w akredytywie. Jeśli bank zaakceptuje dokumentację przedstawioną przez beneficjenta, rozlicza transakcję ze zleceniodawcą, pobierając od niego równowartość kwoty wypłaconej w akredytywie ${ }^{13}$.
\end{abstract}

Akredytywa jest formą zabezpieczenia płatności, dlatego mogłaby być stosowana w przypadku zabytków, które już w momencie sprzedaży posiadają określony zakres prac niezbędnych dla utrzymania dobrego stanu obiektu. Przy sprzedaży nieruchomości przez Skarb Państwa czy JST można byłoby zobowiązać inwestora do otwarcia w banku akredytywy, pokrywającej poszczególne elementy przygotowanego wcześniej kosztorysu rewitalizacji. Ważne jest, że inwestor nie musi posiadać fizycznie gotówki, by móc otworzyć akredytywę. Akredytywa bowiem może zostać otwarta na podstawie kredytu. Akredytywa byłaby formą zabezpieczenia pieniędzy na przeprowadzenie prac przy zabytku. Dawałaby gwarancję, że inwestor posiada środki, by móc wypełniać obowiązki, jakie nakłada na niego ustawa o ochronie zabytków i opiece nad zabytkami. Byłaby formą sprawdzenia, prześwietlenia inwestora/właściciela zabytku pod względem finansowym.

\footnotetext{
12 Ustawa z dnia 29 sierpnia 1997 r. Prawo bankowe, tekst jedn. Dz. U. z 2019 r., poz. 2357 ze zm.

13 Wyrok Wojewódzkiego Sądu Administracyjnego w Krakowie z dnia 8 lipca 2008 r., sygn. akt III SA/Kr 613/07.
} 


\section{DEBIUTY}

Katarzyna Schatt-Babińska

Z pewnością ograniczyłoby to liczbę nieuczciwych nabywców, który skupują zabytki, żeby podwyższyć czy uzyskać powierzchnię użytkowo-mieszkalną, która jest wskaźnikiem przy obliczeniu zdolności kredytowej w bankach. Im jest ona wyższa, tym większy kredyt można zaciągnąć - praktyka ta stosowana jest w Łodzi przez jedną z firm skupującą m.in. zabytkowe obiekty ${ }^{14}$. W jej rękach znajdują się cenne zabytki, takie jak: fabryka Edwarda Hentschela (przy ul. Wólczańskiej 12), kamienica Fischera (na skrzyżowaniu ulic Piotrkowskiej i Zielonej), kamienica Rosenbluma (przy ul. Kościuszki 21), centrala Scheiblerowska (na pl. Zwycięstwa 2) i przędzalnia bawełny Henryka Grohmana (przy ul. Tymienieckiego 22/24). Wszystkie są w złym stanie technicznym - w niektórych obiektach wyburzano ściany, jak w byłej fabryce przy ul. Wólczańskiej 12, przy innych prowadzono prace bez zezwolenia lub nie wykonano pokontrolnych zalecen ${ }^{15}$. Właściciel firmy kupuje od miasta zabytki z 50-procentową bonifikatą przede wszystkim jako nieruchomości do lokowania pieniędzy, ponieważ na nową nieruchomość można wziąć następną pożyczkę lub zastawić ją pod hipotekę ${ }^{16}$.

Akredytywa jest pisemnym zobowiązaniem banku ${ }^{17}$. W takim przypadku w razie niewy wiązania się z umowy przez inwestora WKZ mógłby wykorzystać zabezpieczone środki do zastępczego przeprowadzenia prac. Ważne, aby taka możliwość została ujęta w umowie $z$ bankiem. Taki zapis wyeliminowałby osoby, które chcą kupić zabytek, a nie mają w planach odpowiedniego zajmowania się nim.

W przypadku handlu akredytywa łączy ze sobą trzy podmioty: sprzedającego, kupującego i bank ${ }^{18}$. Przy wykorzystaniu akredytywy do ochrony zabytków podmiotów tych jest więcej: inwestor kupujący zabytek, JTS/Skarb Państwa, które go sprzedają, bank jako gwarant, firma wykonującą określone prace oraz WKZ. W tym

14 S. Bujalski, Łódzkie zabytki popadaja w ruinę. Czy można wygrać z CFI?, „Wyborcza Łódź”, 22.01.2016, http://lodz.wyborcza.pl/lodz/1,44788,19510371,lodzkie-zabytki-popadaja-w-ruine-czy-mozna-wygrac-z-cfi.html [dostęp: 1.06.2020].

15 Archiwum Wojewódzkiego Urzędu Ochrony Zabytków, teczki obiektów: Kamienica Fischera, ul. Piotrkowska 54, nr rej. A/354; Kamienica Rosenbluma, ul. Kościuszki 21; Fabryka Karola Scheiblera, pl. Zwycięstwa 2, nr rej. A/325; Przędzalnia bawełny Henryka Grohmana, ul. Tymienieckiego 22/24, nr rej. A/138. W przypadku fabryki Karola Scheiblera właściciel dopuścił się prowadzenia prac bez zezwolenia postanowił wyczyścić ceglaną elewację zabytkowych zabudowań pofabrycznych za pomocą szlifierki licowej, usuwając wierzchnią warstwę cegieł z naturalnym spiekiem oraz wycinając spoiny. W wyniku tych prac nieodwracalnie zatracono oryginalną substancję zabytku. W przypadku przędzalni bawełny Henryka Grohmana czy kamienicy Rosenbluma właściciel nie wykonał zaleceń po przeprowadzonych przez WKZ lustracjach.

16 Rozmowa z Wojciechem Szygendowskim - pełny opis zob. przypis 10.

17 Wyrok Sądu Apelacyjnego w Warszawie z dnia 31 października 1996 r., sygn. akt I ACr 834/96, OSA 1998/4/16, LEX nr 32837; Z. Ofiarski, Prawo bankowe, Wolters Kluwer Polska, Kraków 2004, s. 139. Zob. I. Heropolitańska, Prawne zabezpieczenia zapłaty wierzytelności, Wolters Kluwer Polska, Warszawa 2018; A. Kawulski, Prawo bankowe. Komentarz, LexisNexis, Warszawa 2013; M. Capiga, Finanse banków, Wolters Kluwer Polska, Warszawa 2011; J. Koleśnik, M. Rewieński, Zabezpieczenia w bankowości - aspekty prawne i wymogi regulacyjne, Wolters Kluwer Polska, Warszawa 2008.

18 Wyrok Sądu Apelacyjnego w Warszawie z dnia 31 października 1996 r., sygn. akt I ACr 834/96, OSA 1998/4/16, LEX nr 32837. 
miejscu należałoby się zastanowić, jak miałaby wyglądać kwestia rozliczenia za wykonane prace. Gdy zleca je inwestor, opcji jest kilka. Po wykonaniu prac i potwierdzeniu przez WKZ, że zostały one przeprowadzone zgodnie z ustaleniami, na podstawie pisma WKZ bank mógłby bezpośrednio rozliczać się z wykonawcami prac. Druga możliwość to rozliczenie za pośrednictwem odpowiedniego urzędu JST jako sprzedającego zabytek - również na podstawie dokumentów przedłożonych przez WKZ. Istnieje jeszcze opcja rozliczenia prac na poziomie wykonawca - WKZ, jednak nie biorą oni bezpośredniego udziału w podpisywaniu umowy kupna-sprzedaży zabytku, więc opcja ta wydaje się być najmniej właściwa. Niemniej nie można odmówić istotnej roli WKZ, jaką odgrywa przy lustracji obiektu po wykonanym remoncie.

Co jednak w przypadku, gdy inwestor nie realizuje uzgodnionych wcześniej zobowiązań? W obecnie obowiązującym systemie prawnym, zgodnie z art. 49 ust. 1 u.o.z., WKZ ma prawo wydania decyzji nakazującej właścicielowi zabytku przeprowadzenie prac konserwatorskich lub robót budowlanych, jeżeli ich wykonanie jest niezbędne dla zachowania obiektu. Niewykonanie ich może skutkować wykonaniem zastępczym wymaganych prac konserwatorskich czy robót budowlanych. Wówczas WKZ wydaje decyzję określającą wierzytelność Skarbu Państwa z tytułu wykonania zastępczego prac (art. 49 ust. 3 u.o.z.), które podlega zabezpieczeniu hipoteką przymusową na tej nieruchomości (art. 49 ust 4 u.o.z.):

\begin{abstract}
z wykonaniem zastępczym mamy do czynienia wówczas, gdy podmiot będący adresatem decyzji nakazowej, o której mowa w art. 49 ust. 1 u.o.z., nie przystąpił do nakazanych prac lub robót albo nie skończył ich w wyznaczonym w tym nakazie terminie. [...] Dopiero po wykonaniu zastępczym, a więc po przeprowadzeniu postępowania egzekucyjnego, będzie mogło dojść do wydania decyzji w kwestii wierzytelności Skarbu Państwa, tj. na podstawie art. 49 ust. 3 i ust. 4 u.o.z [...] decyzje: określająca i zabezpieczająca wierzytelność Skarbu Państwa, mające za podstawę odpowiednio art. 49 ust. 3 i art. 49 ust. 4 u.o.z., mogą być wydane dopiero po zastępczym wykonaniu obowiązków w trybie egzekucji administracyjnym ${ }^{19}$.
\end{abstract}

Jeżeli ściągnięcie wierzytelności spowoduje znaczne pogorszenie sytuacji majątkowej właściciela, wojewoda w porozumieniu z Generalnym Konserwatorem Zabytków może umorzyć kwotę wierzytelności w całości lub części lub rozłożyć ją na raty (art. 49 ust 6 u.o.z.). Jednak jak zostało podkreślone w odpowiedzi podsekretarza stanu w Ministerstwie Kultury i Dziedzictwa Narodowego - z upoważnienia ministra - na interpelację nr 9707 w sprawie zespołu pałacowo-parkowego w Gorzanowie:

w przypadku braku możliwości zabezpieczenia środków na zastępcze wykonanie prac konserwatorskich i robót budowlanych przy zabytkowym zespole w Gorzanowie wy-

19 Wyrok Wojewódzkiego Sądu Administracyjnego w Warszawie z dnia 23 stycznia 2019 r., sygn. akt VII SA/Wa 662/18, LEXnr 2638745. 


\section{DEBIUTY}

Katarzyna Schatt-Babińska

dawanie decyzji, o której mowa w art. 49 ust. 1 ustawy o ochronie zabytków i opiece nad zabytkami, nie będzie stanowiło skutecznego sposobu zapewnienia jego utrzymania we właściwym stanie ${ }^{20}$.

Do wykonania zastępczego mają zastosowanie przepisy działu III rozdziału 3 (art. 127-135) ustawy z dnia 17 czerwca 1966 r. o postępowaniu egzekucyjnym w administracji ${ }^{21}$ (dalej: u.p.e.a.). Wykonanie zastępcze stosuje się, gdy egzekucja dotyczy obowiązku wykonania czynności, którą można zlecić innej osobie do wykonania za zobowiązanego i na jego koszt (art. 127 u.p.e.a.). W celu zastosowania tego środka egzekucyjnego organ egzekucyjny doręcza zobowiązanemu odpis tytułu wykonawczego oraz postanowienie, że obowiązek objęty tytułem wykonawczym zostanie $w$ trybie postępowania egzekucyjnego wykonany zastępczo przez inną osobę za zobowiązanego, na jego koszt i niebezpieczeństwo (art. 128 ust. 1 u.p.e.a.). Dopiero po wykonaniu zastępczym WKZ ma prawo wydania decyzji w kwestii wierzytelności Skarbu Państwa ${ }^{22}$. Zgodnie z art. 134 u.p.e.a., jeżeli zobowiązany nie wpłacił w oznaczonym terminie określonej w postanowieniu o zastosowaniu wykonania zastępczego kwoty tytułem zaliczki na koszty wykonania zastępczego (art. 128 § 2) lub kwoty na pokrycie kosztów wykonania zastępczego wskazanej w dostarczonych wykazach, organ egzekucyjny wszczyna egzekucję tych należności stosownie do przepisów o egzekucji administracyjnej należności pieniężnych.

Otwarcie akredytywy w banku przez inwestora ogranicza ryzyko związane z rozliczeniem płatności za przeprowadzenie niezbędnych i zaplanowanych wcześniej prac przy zabytku - jest swoistą gwarancją posiadania przez niego środków pieniężnych i chroni również przed jego nieuczciwością. Jeżeli jednak z jakichś przyczyn inwestor nie rozpocząłby zaplanowanych prac, wówczas fundusze z akredytywy JST/Skarb Państwa w porozumieniu z WKZ mógłby wykorzystać na zastępcze ich wykonanie. Obecnie przepis o zastępczym wykonaniu prac przy zabytku nie jest często wykorzystywany, głównie z powodu braku funduszy na przeprowadzenie $\operatorname{prac}^{23}$.

Problem ze stosowaniem remontu zastępczego przez konserwatora wojewódzkiego jest dwojaki, po pierwsze ze względu na skromny budżet działania takie ograniczają się do wykonania najwyżej jednego remontu w roku i to pod warunkiem, że nie są

20 Odpowiedź podsekretarza stanu w Ministerstwie Kultury i Dziedzictwa Narodowego - z upoważnienia ministra - na interpelację nr 9707 w sprawie zespołu pałacowo-parkowego w Gorzanowie, pow. kłodzki, woj. dolnośląskie, http://orka2.sejm.gov.pl/IZ6.nsf/main/1D8AC1BC [dostęp: 01.06.2020].

21 Ustawa z dnia 17 czerwca 1966 r. o postępowaniu egzekucyjnym w administracji, Dz. U. z 2018 r., poz. 1314.

22 Wyrok Wojewódzkiego Sądu Administracyjnego w Warszawie z dnia 23 stycznia 2019 r., sygn. akt VII SA/Wa 662/18, LEX nr 2638745.

23 Najwyższa Izba Kontroli o ochronie zabytków, https://www.nik.gov.pl/aktualnosci/nik-o-ochronie-zabytkow.html [dostęp: 1.06.2020]. 
to skomplikowane i kosztowne roboty (W sumie w większości urzędów konserwatorskich ze względu na brak środków finansowych nie stosuje się tych działań). Drugim problemem są kwestie proceduralne, do tego złożone i nieuregulowane sprawy własnościowe lub też problemy z odnalezieniem właścicieli ${ }^{24}$.

Ważne jest, aby w treści akredytywy zostały określone dokumenty, na podstawie których bank ma wypłacić pieniądze ${ }^{25}$. Obecnie nie obowiązują określone ustawą formy ani treści otwarcia akredytywy - jej treść, warunki są do uzgodnienia między zleceniodawcą a beneficjentem akredytywy ${ }^{26}$.

\section{Gwarancja bankowa}

Gwarancja bankowa to swoista forma gwarancji, w której rolę gwaranta przyjmuje bank. Umowa gwarancji bankowej jest, podobnie jak w przypadku akredytywy, pisemnym zobowiązaniem banku do zapłaty beneficjentowi gwarancji kwoty maksymalnej wskazanej w gwarancji, jeśli zleceniodawca gwarancji, na którego została wystawiona, nie wywiąże się ze swojego zobowiązania ${ }^{27}$. W tej sytuacji na poziomie handlowym mamy trzy podmioty: zlecającego udzielenie gwarancji, bank oraz beneficjenta gwarancji ${ }^{28}$. Analogicznie jak przy wykorzystaniu akredytywy, na poziomie ochrony zabytków zlecającym otworzenie gwarancji byłby inwestor, natomiast Skarb Państwa czy JST sprzedająca nieruchomość przejęłyby rolę beneficjenta gwarancji. Jeżeli inwestor wywiąże się z umowy realizacji prac, wówczas gwarancja nie zostaje wykorzystana, jest bowiem formą zabezpieczenia. Jednak w przypadku nieprzeprowadzenia przy zabytku niezbędnych opisanych w umowie prac, na zlecenie gminy WKZ mógłby zabezpieczoną kwotę wykorzystać, realizując zaplanowane prace. W tym wypadku niezbędną stroną jest jeszcze firma przeprowadzająca roboty. I to ona finalnie, po realizacji zaplanowanych prac, powinna otrzymać zabezpieczone środki finansowe. Mogłaby rozliczyć się z określoną JST lub Skarbem Państwa na podstawie pozytywnego wyniku lustracji wykonanej przez WKZ. Istnieje jeszcze opcja bezpośredniego

\footnotetext{
24 I. Solisz, Podsumowanie działań OWKZ w zakresie zagrożonych pałaców, http://www.wuozopole.pl/18-polecamy/edd/18-obiekty-zagrozone [dostęp: 1.06.2020].

25 J. Pisuliński, Prawo bankowe, LexisNexis, Warszawa 1999, s. 304-305.

26 Wyrok Wojewódzkiego Sądu Administracyjnego w Krakowie z dnia 8 lipca 2008 r., sygn. akt III SA/Kr 613/07, LEX nr 498212; B. Smykla, Prawo bankowe. Komentarz, C.H. Beck, Warszawa 2011, s. 344-345.

27 Redakcja glosy, materiały źródłowe Narodowego Banku Polskiego, pismo z dnia 8 sierpnia $1996 \mathrm{r}$. Narodowy Bank Polski Zespół ds. Interpretacji Prawnych NB/ZIP/680/96 kredytywa "stand-by” a gwarancja bankowa, LEX Glosa 1997/9/22-26; Wyrok Sądu Najwyższego z dnia 20 września 2013 r., sygn. akt II CSK 670/12, OSNC 2014/5/53; T. Narożny, Czynności kredytowe banku - zagadnienia prawne, Wydawnictwo Zarządzanie i Finanse, Warszawa 2000, s. 147.

28 Wyrok Sądu Najwyższego z dnia 27 marca 2013 r., sygn. akt I CSK 630/12, LEX nr 1341650; Wyrok Sądu Najwyższego z dnia 15 września 2016 r., sygn. akt CSK 524/15, LEX nr 2153422.
} 


\section{DEBIUTY}

Katarzyna Schatt-Babińska

rozliczenia się między bankiem a firmą przeprowadzającą poszczególne prace. Jednak JST jako instytucja zaufania publicznego wydaje się być bezpieczniejszą opcją. Treść umowy gwarancji, podobnie jak w przypadku akredytywy, może zostać ułożona w granicach swobodnego uznania ${ }^{29}$, powinna jednak określać konkretny termin, z którego upływem wygasa odpowiedzialność banku ${ }^{30}$, oraz szczegółowe wymogi realizacji gwarancji31:

Takie dodatkowe postanowienia umowy gwarancyjnej mogą służyć pewniejszemu wykazaniu wystąpienia zdarzeń objętych gwarancją oraz identyfikowaniu podmiotu uprawnionego do wypłaty sumy gwarancyjnej. W szczególności więc w treści umowy gwarancji bankowej mogą się znaleźć szczegółowe postanowienia dotyczące treści i sposobu zgłoszenia gwarantowi żądania, jako niezbędne wymagania powstania skutecznego roszczenia o wypłatę sumy gwarancyjnej ${ }^{32}$.

W przypadku gwarancji jako zobowiązania banku należy pamiętać, że rozmiar jego odpowiedzialności jest z góry określony w umowie za pomocą sumy gwarancyjnej uzgodnionej przez wszystkie strony. Nie ma na to wypływu rozmiar poniesionej przez beneficjenta szkody ${ }^{33}$.

Gwarancja bankowa jest wykorzystywana w prawie ochrony środowiska jako forma zabezpieczenia roszczeń z tytułu wystąpienia negatywnych skutków w środowisku oraz szkód w środowisku (art. 187 ustawy z dnia 27 kwietnia 2001 r. Prawo ochrony środowiska ${ }^{34}$ ). Gwarancję bankową, depozyt lub polisę ubezpieczeniową stosuje się, jeżeli przemawia za tym szczególnie ważny interes społeczny związany z ochroną środowiska, a w szczególności z zagrożeniem pogorszenia stanu środowiska w znacznym stopniu. Dotyczy to przedsiębiorców starających się o pozwolenia zintegrowane, na wprowadzanie gazów lub pyłów do powietrza, na wytwarzanie odpadów, na wprowadzanie ścieków do wód lub do ziemi, na emitowanie hałasu i pól elektromagnetycznych. W tym przypadku gwarancja bankowa powinna stwierdzać, że $w$ razie wystąpienia negatywnych skutków w środowisku w wyniku niewywiązania się przez podmiot z obowiązków określonych

29 Wyrok Sądu Najwyższego z dnia 29 listopada 2013 r., sygn. akt I CSK 90/13, LEX nr 1480005. Zob. E. Fojcik-Mastalska (red.), Prawo bankowe. Komentarz, LexisNexis, Warszawa 2008; F. Zoll (red.), Prawo bankowe. Komentarz, Wydawnictwo Zakamycze, Kraków 2005; A. Kidyba (red.), Umowy w obrocie gospodarczym. Wzory. Komentarze. Orzecznictwo, Wolters Kluwer Polska, Warszawa 2018.

30 J. Pisuliński, Niektóre zagadnienia zwiqzane z gwarancją bankową, „Prawo Bankowe” 1998, nr 4, s. 37.

31 A. Maciejewski, Spory wynikające z niezasadnego skorzystania przez inwestora z gwarancji bankowej lub ubezpieczeniowej zabezpieczajacej należyte wykonanie umowy o roboty budowlane - wybrane zagadnienia, „Przegląd Sądowy” 2017, nr 5, s. 101-116.

32 Wyrok Sądu Apelacyjnego w Warszawie z dnia 9 kwietnia 2015 r., sygn. akt VI ACa991/14, LEX nr 1754030.

33 Wyrok Sądu Najwyższego z dnia 20 grudnia 1996 r., sygn. akt I CKU 30/96, LEX nr 1095807.

34 Ustawa z dnia 27 kwietnia 2001 r. Prawo ochrony środowiska, tekst jedn. Dz.U. z 2019 r., poz. 1396 ze zm. 
w pozwoleniu bank ureguluje zobowiązania na rzecz organu wydającego pozwolenie (art. 187, ust. 4 Prawa ochrony środowiska). Wysokość zabezpieczenia ustala organ administracji wydający pozwolenie, a kwota

powinna być dostosowana do skali zagrożeń wynikających z działalności, w związku z wykonywaniem której eksploatowana jest instalacja wymagająca uzyskania pozwolenia na korzystanie ze środowiska oraz ustalenia ewentualnych kosztów przywrócenia środowiska do stanu poprzedniego w przypadku jego degradacji. Wynika z tego, że ustanowienie zabezpieczenia poprzedzać powinna analiza przeprowadzona w powyższym zakresie. W uzasadnieniu wydawanej decyzji organ powinien dać wyraz zasadności ustalonej kwoty zabezpieczenia finansowego ${ }^{35}$.

W przypadku ochrony zabytków kwotę zabezpieczenia powinien ustalać zespół osób pracujących w wojewódzkim urzędzie ochrony zabytków. Opinia w sprawie kwoty zabezpieczenia powinna być przekazana organowi administracji odpowiedzialnemu za sprzedaż zabytkowej nieruchomości.

\section{Zakończenie}

Akredytywa i gwarancja bankowa od lat z sukcesem wykorzystywane są w transakcjach handlowych. Jak wynika z badań Międzynarodowej Izby Handlu (International Chamber of Commerce), ten sposób rozliczeń w 2017 r. stanowił 49\% badanych transakcji ${ }^{36}$.

Wprowadzenie do ochrony zabytków instrumentów finansowych takich jak akredytywa dokumentowa czy gwarancja bankowa może budzić wiele zastrzeżeń co do zmiany obowiązujących przepisów. Istnieje również ryzyko zmniejszenia liczby osób zainteresowanych kupnem zabytkowej nieruchomości. Można natomiast przewidzieć, że grupa osób chcących kupić zabytek zmniejszyłaby się o tych, którzy nie posiadają funduszy, by się nimi zajmować ${ }^{37}$. Wprowadzenie zaproponowanych instrumentów finansowych z dużym prawdopodobieństwem mogłoby wyeliminować z obiegu nieuczciwych inwestorów. Jeżeli inwestor wiedziałby, że nawet jeśli nie wykona zaplanowanych prac czy nie będzie chciał sfinansować niezbędnych robót przy obiekcie, JST czy Skarb Państwa zgodnie z umową pobiorą zgromadzone środki na ich wykonanie, nie kupowałby zabytku,

\footnotetext{
35 D. Maśniak, Interes społeczny a przymus w ubezpieczeniach rolnych i ekologicznych, „Gdańskie Studia Prawnicze" 2012, t. 27, s. 229.

36 ICC Global Survey on Trade Finance 2018/Where banks stand on strategy and operations, w: 2018 Global Trade - Securing Future Growth. ICC Global Survey on Trade Finance, International Chamber of Commerce Paris 2018, s. 46, https://iccwbo.org/content/uploads/sites/3/2018/05/icc-2018-global-trade-securing-futuregrowth.pdf [dostęp: 1.06.2020].

37 Mowa oczywiście o grupie osób, które chcą kupić zabytek wystawiony na sprzedaż przez JST czy Skarb Państwa. Nie ma możliwości prawnych, by zobowiązać osoby fizyczne zawierające umowę kupna-sprzedaży, by ustaliły między sobą, kto sfinansuje przeprowadzenie prac.
} 


\section{DEBIUTY}

Katarzyna Schatt-Babińska

zakładając wcześniej, że nie będzie wypełniał obowiązków nałożonych na niego przez ustawę o ochronie zabytków i opiece nad zabytkami.

Można się zastanawiać, czy jest w ogóle sens rozpatrywania wprowadzenia zaproponowanych zmian, skoro funkcjonuje Narodowy Fundusz Ochrony Zabytków. Opisane instrumenty finansowania mogłyby skutecznie wesprzeć Fundusz. Wprowadzenie akredytywy i gwarancji bankowej do systemu ochrony zabytków usprawniłoby wykorzystanie zabezpieczonych pieniędzy na przeprowadzenie niezbędnych przy nich prac. Sama procedura ich wypłacenia może trwać krócej niż procedura finansowania prac z pieniędzy z Funduszu, a przy pracach ratunkowych i konserwatorskich przy zabytkach czas gra zasadniczą rolę. Trzeba również mieć na uwadze, że akredytywa i gwarancja bankowa są możliwe do zastosowania tylko przy zabytkach sprzedawanych przez JST czy Skarb Państwa.

Odpowiednie zmiany należałoby wprowadzić w przepisach dotyczących gospodarki nieruchomościami lub sposobów i trybów przeprowadzania przetargów. Po wygraniu przetargu dany inwestor przed podpisaniem umowy sprzedaży byłby zobligowany do przedstawienia sprzedającemu i WKZ pisma z banku potwierdzającego otwarcie akredytywy czy gwarancji bankowej. W przepisach należałoby również uwzględnić sposób postępowania w przypadku niewywiązania się z umowy przez inwestora, aby WKZ mógł wykorzystać zabezpieczone środki do zastępczego przeprowadzenia prac. Pomocnym narzędziem, zwłaszcza w przypadku gwarancji bankowej otwieranej przy sprzedaży zabytku, który wymaga przeprowadzenia konkretnych prac, byłaby dokładna analiza stanu zabytku z wyszczególnieniem niezbędnych do wykonania prac wraz z inwentaryzacją i opis stanu technicznego zabytku. Przygotowanie takiego dokumentu należałoby do zadań WKZ.

Wprowadzenie akredytywy i gwarancji bankowej jako zabezpieczenia niezbędnych funduszy na remont w przypadku sprzedaży prywatnemu inwestorowi zabytku przez Skarb Państwa lub JST wymagałoby wdrożenia konkretnych rozwiązań w przepisach prawnych, ale mogłyby one stać się użytecznym narzędziem w finansowaniu niezbędnych prac przy zabytkach i uchronić je przed degradacją. Umożliwiłyby zabezpieczenie płatności za przeprowadzenie prac lub zabezpieczenie pieniędzy na wykonanie niezbędnych remontów.

\section{Bibliografia}

Archiwum Wojewódzkiego Urzędu Ochrony Zabytków, teczki obiektów: Kamienica Fischera, ul. Piotrkowska 54, nr rej. A/354; Kamienica Rosenbluma, ul. Kościuszki 21; Fabryka Karola Scheiblera, pl. Zwycięstwa 2, nr rej. A/325; Przędzalnia bawełny Henryka Grohmana, ul. Tymienieckiego 22/24, nr rej. A/138.

Bujalski S., Łódzkie zabytki popadaja w ruinę. Czy można wygrać z CFI?, „Wyborcza Łódź”, 22.01.2016, http://lodz.wyborcza.pl/lodz/1,44788,19510371,lodzkie-zabytki-popadaja-w-ruine-czy-mozna-wygrac-z-cfi.html [dostęp: 1.06.2020].

Capiga M., Finanse banków, Wolters Kluwer Polska, Warszawa 2011. 
Fojcik-Mastalska E. (red.), Prawo bankowe. Komentarz, LexisNexis, Warszawa 2008.

Heropolitańska I., Prawne zabezpieczenia zapłaty wierzytelności, Wolters Kluwer Polska, Warszawa 2018.

ICC Global Survey on Trade Finance 2018/Where banks stand on strategy and operations, w: 2018 Global Trade - Securing Future Growth. ICC Global Survey on Trade Finance, International Chamber of Commerce Paris 2018, https://iccwbo.org/content/ uploads/sites/3/2018/05/icc-2018-global-trade-securing-future-growth.pdf [dostęp: 1.06.2020].

Kawulski A., Prawo bankowe. Komentarz, LexisNexis, Warszawa 2013.

Kidyba A. (red.), Umowy w obrocie gospodarczym. Wzory. Komentarze. Orzecznictwo, Wolters Kluwer Polska, Warszawa 2018.

Koleśnik J., Rewieński M., Zabezpieczenia w bankowości - aspekty prawne i wymogi regulacyjne, Wolters Kluwer Polska, Warszawa 2008.

Maciejewski A., Spory wynikajace z niezasadnego skorzystania przez inwestora z gwarancji bankowej lub ubezpieczeniowej zabezpieczajacej należyte wykonanie umowy o roboty budowlane - wybrane zagadnienia, „Przegląd Sądowy” 2017, nr 5.

Maśniak D., Interes społeczny a przymus w ubezpieczeniach rolnych i ekologicznych, „Gdańskie Studia Prawnicze" 2012, t. 27.

Najwyższa Izba Kontroli o ochronie zabytków, https://www.nik.gov.pl/aktualnosci/nik-o-ochronie-zabytkow.html [dostęp: 1.06.2020].

Narożny T., Czynności kredytowe banku - zagadnienia prawne, Wydawnictwo Zarządzanie i Finanse, Warszawa 2000.

Odpowiedź podsekretarza stanu w Ministerstwie Kultury i Dziedzictwa Narodowego z upoważnienia ministra - na interpelację nr 9707 w sprawie zespołu pałacowo-parkowego w Gorzanowie, pow. kłodzki, woj. dolnośląskie, http://orka2.sejm.gov.pl/IZ6. nsf/main/1D8AC1BC [dostęp: 1.06.2020].

Ofiarski Z., Prawo bankowe, Wolters Kluwer Polska, Kraków 2004.

Pisuliński J., Niektóre zagadnienia związane z gwarancją bankowa, „Prawo Bankowe” 1998, $\mathrm{nr} 4$.

Pisuliński J., Prawo bankowe, LexisNexis, Warszawa 1999.

Redakcja glosy, materiały źródłowe Narodowego Banku Polskiego, pismo z dnia 8 sierpnia 1996 r. Narodowy Bank Polski Zespół ds. Interpretacji Prawnych NB/ZIP/680/96 kredytywa "stand-by” a gwarancja bankowa, LEX Glosa 1997/9/22-26.

Rozbicka M. (red.), Raport o stanie zachowania zabytków nieruchomych w Polsce. Zabytki wpisane do rejestru zabytków (księgi rejestru A i C), Narodowy Instytut Dziedzictwa, Warszawa 2017.

Schatt-Babińska K., Zabytki nieruchome w rękach prywatnych - historia, zagadnienia ochrony i konserwacji na przykładach obiektów wpisanych do rejestru zabytków w Łodzi, praca doktorska przygotowana pod kierunkiem prof. dr. hab. K. Stefańskiego, obroniona 16.01.2020 r. na Wydziale Filozoficzno-Historycznym Uniwersytetu Łódzkiego.

Smykla B., Prawo bankowe. Komentarz, C.H. Beck, Warszawa 2011.

Solisz I., Podsumowanie działań OWKZ w zakresie zagrożonych pałaców, http://www.wuozopole.pl/18-polecamy/edd/18-obiekty-zagrozone [dostęp: 1.06.2020]. 


\section{DEBIUTY}

Katarzyna Schatt-Babińska

Ustawa z dnia 17 czerwca 1966 r. o postępowaniu egzekucyjnym w administracji, Dz. U. z 2018 r., poz. 1314.

Ustawa z dnia 21 sierpnia 1997 r. o gospodarce nieruchomościami, tekst jedn. Dz.U. z 2020 r., poz. 65 ze zm.

Ustawa z dnia 29 sierpnia 1997 r. Prawo bankowe, tekst jedn. Dz. U. z 2019 r., poz. 2357 ze zm.

Ustawa z dnia 27 kwietnia 2001 r. Prawo ochrony środowiska, tekst jedn. Dz.U. z 2019 r., poz. 1396 ze zm.

Ustawa z dnia 23 lipca 2003 r. o ochronie zabytków i opiece nad zabytkami, tekst jedn. Dz.U. z 2020 r., poz. 282 ze zm.

Ustawa z dnia 22 czerwca 2017 r. o zmianie ustawy o ochronie zabytków i opiece nad zabytkami oraz niektórych innych ustaw, Dz. U. poz. 1595.

Wyrok Sądu Apelacyjnego w Warszawie z dnia 31 października 1996 r., sygn. akt I ACr 834/96, OSA 1998/4/16, LEX nr 32837.

Wyrok Sądu Apelacyjnego w Warszawie z dnia 9 kwietnia 2015 r., sygn. akt VI ACa991/14, LEX nr 1754030.

Wyrok Sądu Najwyższego z dnia 20 grudnia 1996 r., sygn. akt I CKU 30/96, LEX nr 1095807.

Wyrok Sądu Najwyższego z dnia 27 marca 2013 r., sygn. akt I CSK 630/12, LEX nr 1341650.

Wyrok Sądu Najwyższego z dnia 20 września 2013 r., sygn. akt II CSK 670/12, OSNC 2014/5/53.

Wyrok Sądu Najwyższego z dnia 29 listopada 2013r., sygn. akt I CSK 90/13, LEXnr 1480005.

Wyrok Sądu Najwyższego z dnia 15 września 2016 r., sygn. akt CSK 524/15, LEXnr 2153422.

Wyrok Wojewódzkiego Sądu Administracyjnego w Krakowie z dnia 8 lipca 2008 r., sygn. akt III SA/Kr 613/07, LEX nr 498212.

Wyrok Wojewódzkiego Sądu Administracyjnego w Warszawie z dnia 23 stycznia 2019 r., sygn. akt VII SA/Wa 662/18, LEX nr 2638745.

Zalasińska K., Narodowy Fundusz Ochrony Zabytków - w kierunku systemowych zmian w ochronie zabytków, „Cenne, Bezcenne, Utracone” 2019, nr 1-2, http://cennebezcenne.pl/wpcontent/uploads/2019/09/2019-1-2-ZALASINSKA.pdf [dostęp: 1.06.2020].

Zoll F. (red.), Prawo bankowe. Komentarz, Wydawnictwo Zakamycze, Kraków 2005. 